\title{
ANALISIS FAKTOR-FAKTOR YANG MEMENGARUHI PENYALURAN KREDIT PADA BANK KONVENSIONAL PERIODE 2015-2019
}

\author{
Rurun Ayu Anggraini \\ Universitas Negeri Surabaya \\ rurun.17080574080@mhs.unesa.ac.id
}

\begin{abstract}
Lending to conventional banks is an activity that will generate profits for the banks, and with credit, it can improve the welfare of people in a country. The purpose of this study is to determine the effect of Third Party Funds (TPF), Capital Adequacy Ratio (CAR), Return on Assets (ROA), Non Performing Loans (NPL), and Loan to Deposit Ratio (LDR) on credit disbursement at conventional banks period year 2015-2019. This study uses quantitative data types with associative methods. The sample is 24 banks with a purposive sampling method. The data analysis technique used is multiple linear regression using the SPSS software application. The results show that TPF and LDR had a positive and significant effect on lending. CAR, ROA, and NPL did not affect distribution credit. However, simultaneously the independent variables affect the dependent variable (credit distribution). Banks as providers of funds must pay attention to the factors that influence lending so that both banks, users of funds, and the government can benefit from the provision of these funds.
\end{abstract}

Keywords: CAR; loan to deposit ratio; NPL; ROA; third party funds.

\section{PENDAHULUAN}

Perkembangan era globalisasi saat ini yang semakin maju membuat banyaknya masyarakat memerlukan dana guna mencukupi kebutuhan sehari-hari, guna membuka usaha ataupun untuk meningkatkan usahanya agar dapat bersaing dengan perusahaan lain. Era globalisasi dapat menghubungkan negara-negara yang akan membuka peluang pasar dan menyebabkan masuknya produk-produk global sehingga perusahaan domestik akan membutuhkan dana untuk dapat bersaing serta era globalisasi dapat menghilangkan batasan antar negara dalam kegiatan ekonomi sehingga membuat masyarakat mebutuhkan dana karena banyaknya persaingan (Indomaritim.id, 2020). Bank merupakan bagian penting yang berperan dalam pembangunan ekonomi (Putri \& Akmalia, 2016). Menurut Latumaerissa (2013), bank adalah lembaga keuangan yang menerima simpanan dari masyarakat dan mengalokasikanya kembali kepada masyarakat agar memperoleh keuntungan dan menyediakan jasa keuangan untuk lalu lintas pembayaran. Bank akan memperoleh keuntungan yang berasal dari jasa-jasa yang terdapat pada perbankan dan dana simpanan yang berasal dari masyarakat yang diputar dan dialokasikan. Menurut Rivai et al. (2013), bank dapat dikatakan sebagai financial intermediary di mana kegiatan perusahaanya mendapat dari masyarakat berbentuk simpanan serta menyalurkan kembali ke masyarakat berupa kredit. Penyaluran kredit menjadi bagian penting pada perbankan dikarenakan penyaluran kredit dapat menyejahterakan masyarakat, penyaluran kredit akan membuat bank mendapatkan laba, di mana laba merupakan sumber utama pendapatan bank (Ayu \& Purnawati, 2017).

Bank konvensional memiliki peranan penting dalam penyaluran kredit di Indonesia, di mana bank konvensional memiliki tingkat penyaluran kredit yang tinggi terbukti dengan adanya peningkatan penyaluran kredit tiap tahunnya mulai 2015-2019 (www.ojk.co.id, 2020). Penyaluran kredit yang dilakukan bank konvensional untuk masyarakat di Indonesia mengalami peningkatan dari tahun ke tahun tetapi kredit tersebut memiliki risiko yang cukup besar, maka dari itu pada kegiatan yang dilakukan perbankan perlu dilakukan analisis risiko kredit serta prinsip kehati-hatian (Ayu \& Purnawati, 2017). Berdasarkan data Otoritas Jasa Keuangan (OJK), terdapat peningkatan kredit tahun 2015 sebesar 10,1\% dan tahun 2016 penyaluran kredit mengalami peningkatan sebesar 7,87\% (www.ojk.co.id, 2020). Selama tahun 2017, kredit juga mengalami pertumbuhan hanya saja kredit tahun 2017 hanya meningkat sebesar 8,24\% (CNN, 2017). Tahun 2018 merupakan waktu kebangkitan bagi pertumbuhan kredit perbankan. Otoritas Jasa Keuangan (OJK) mendata penyaluran kredit meningkat sebesar 12,88\% selama tahun 2018 (CNN, 2019). Meskipun terdapat tekanan yang berasal 
Rurun Ayu Anggraini. Analisis Faktor-faktor yang Memengaruhi Penyaluran Kredit pada Bank Konvensional Periode 2015-2019

dari ekonomi global, terutama berdasarkan otoritas normalisasi moneter Bank Sentral Amerika Serikat (AS), penyaluran kredit bank dinyatakaan cukup meningkat (CNN, 2019). Dibandingkan tahun 2018, peningkatan kredit tahun 2019 hanya meningkat 6,08\% (CNN, 2020). Tampilan data mengenai penyaluran dan pertumbuhan kredit bank umum konvensional dapat dilihat di Tabel 1.

Tabel 1.

JUMLAH PENYALURAN KREDIT, DPK, CAR, ROA, NPL, DAN LDR BANK KONVENSIONAL TAHUN 2015-2019 (MILIAR RUPIAH)

\begin{tabular}{lccccc}
\hline \multicolumn{1}{c}{ Tahun } & $\mathbf{2 0 1 5}$ & $\mathbf{2 0 1 6}$ & $\mathbf{2 0 1 7}$ & $\mathbf{2 0 1 8}$ & $\mathbf{2 0 1 9}$ \\
\hline Kredit & $4,057,904$ & $4,377,195$ & $4,548,155$ & $5,092,584$ & $5,391,846$ \\
DPK & $4,238,349$ & $4,836,758$ & $5,050,984$ & $5,372,841$ & $5,709,670$ \\
CAR $(\%)$ & 21.39 & 22.69 & 23.18 & 22.97 & 23.40 \\
ROA & 2.32 & 2.17 & 2.45 & 2.55 & 2.47 \\
NPL & 1.14 & 1.24 & 1.11 & 1.00 & 1.16 \\
LDR & 92.11 & 90.50 & 90.04 & 94.78 & 94.43 \\
\hline
\end{tabular}

Sumber: www.ojk.co.id (2020, data diolah)

Tabel 1 menunjukkan kredit yang diberikan bank konvensional selama tahun 2015-2019 setiap tahunnya meningkat yakni di tahun 2015 sejumlah 3.904.158 miliar serta pada tahun 2019 sejumlah 5.391.846 miliar. Dana pihak ketiga yang berupa tabungan, giro, dan deposito juga mengalami peningkatan setiap tahunnya yaitu pada 2015 sejumlah 4.238 .349 miliar hingga pada 2019 sejumlah 5.709.670 miliar (www.ojk.co.id, 2020). Menurut Ayu \& Purnawati (2017), dana pihak ketiga berpengaruh positif terhadap penyaluran kredit, sedangkan menurut Wulandari (2013), DPK tidak berpengaruh terhadap penyaluran kredit.

Sementara itu, Capital Adequacy Ratio (CAR) mengalami peningkatan pada tahun 2015 hingga tahun 2017 tetapi pada tahun 2018 CAR mengalami penurunan sejumlah 22,97\%. Pada tahun 2019 CAR mengalami peningkatan sebesar 23,40\% (www.ojk.co.id, 2020). CAR memiliki pengaruh signifikan positif terhadap penyaluran kredit (Amelia \& Murtiasih, 2017). Menurut Panuntun \& Sutrisno (2018), CAR memiliki pengaruh signifikan negatif terhadap penyaluran kredit. Berbeda dengan Ayu \& Purnawati (2017), CAR tidak memiliki pengaruh terhadap penyaluran kredit.

Di sisi lain, Return on Assets (ROA) mengalami peningkatan pada tahun 2015 tetapi di tahun 2016 ROA mengalami penurunan menjadi 2,17\%. Tahun 2017-2019, ROA mengalami peningkatan setiap tahunnya (www.ojk.co.id, 2020). Putri \& Akmalia (2016) berpendapat bahwa Return on assets (ROA) berpengaruh positif signifikan terhadap penyaluran kredit. ROA berpengaruh signifikan negatif terhadap penyaluran kredit (Syukriyah et al., 2018). Sedangkan, Febrianto (2013) menyatakan ROA tidak memiliki pengaruh terhadap penyaluran kredit.

Non Performing Loan (NPL) mengalami peningkatan pada 2015 dan 2016 yaitu sebesar 1,14\% menjadi sebesar 1,24 \% dan tahun selanjutnya Non Performing Loan (NPL) turun tetapi tahun 2019. Non Performing Loan (NPL) meningkat kembali sebesar 1,16\% karena Non Performing Loan (NPL) yang baik memiliki persentase yang rendah. Menurut Yasnur \& Kurniasih (2017), NPL berpengaruh positif signifikan terhadap penyaluran kredit. Hal ini berbeda dengan Syukriyah et al. (2018) yang menyatakan NPL berpengaruh negatif signifikan terhadap penyaluran kredit, sedangkan menurut Panuntun \& Sutrisno (2018), NPL tidak berpengaruh terhadap penyaluran kredit.

Loan to Deposit Ratio (LDR) mengalami penurunan tiap tahunnya dari tahun 2015 hingga tahun 2017, tetapi di tahun 2018 LDR mengalami peningkatan sebesar 94,78\% dan tahun 2019 LDR mengalami penurunan sebesar 94, 43\% (www.ojk.co.id, 2020). Menurut Amelia \& Murtiasih (2017), LDR berpengaruh positif signifikan terhadap penyaluran kredit berbeda dengan Panuntun \& Sutrisno (2018) yang menyatakan LDR berpengaruh negatif signifikan terhadap penyaluran kredit, tetapi menurut Putri \& Akmalia (2016), LDR tidak berpengaruh terhadap penyaluran kredit. 
Tujuan penelitian ini untuk mengetahui pengaruh variabel Dana Pihak Ketiga (DPK), Capital Adequacy Ratio (CAR), Return on Assets (ROA), Non Performing Loan (NPL), dan Loan to Deposit Ratio terhadap penyaluran kredit pada bank konvensional periode 2015-2019.

\section{KAJIAN PUSTAKA DAN PENGEMBANGAN HIPOTESIS}

\section{Signalling Theory}

Menurut Nuswandari (2009), teori sinyal adalah teori yang menerangkan mengapa perusahaan harus memiliki motif untuk memberi informasi laporan keuangan ke pihak eksternal. Signalling theory menerangkan bahwa bagaimana semestinya sebuah bank menyampaikan indikasi pada seluruh masyarakat yang menggunakan laporan keuangan bank. Pemberian sinyal bisa berbentuk informasi perihal apa saja yang akan dilaksanakan manajemen agar dapat mewujudkan kemauan pemilik. Sinyal tersebut juga bisa berbentuk promosi ataupun sinyal yang menerangkan bahwa sebuah bank tersebut dapat menjadi baik dari bank yang lainya (Nuswandari, 2009).

Signalling theory menyatakan bahwa bagaimana sinyal dapat memengaruhi penerima sinyal melalui informasi yang ada pada laporan keuangan. Sehingga sesorang yang menerima sinyal dapat menilai sinyal tersebut sebagai informasi untuk digunakan untuk mengambil keputusan kedepanya. Untuk masyarakat yang menggunakan laporan keuangan perbankan dapat memanfaatkan rasio-rasio yang ada untuk memahami tingkat kesehatan perbankan yang dapat bermanfaat untuk mengambil keputusan dan strategi kedepannya (Purnamasari \& Musdholifah, 2018).

\section{Kredit}

Kredit berdasarkan bahasa latin disebut credere. Credere memiliki arti percaya di mana percaya memiliki arti bahwa kreditur yakin terhadap debitur akan kredit yang disalurkan dapat kembali tepat sesuai janji yang disetuji kedua belah pihak (Febrianto, 2013). Sudut pandang debitur, percaya bermakna debitur memperoleh kepercayaan, maka debitur wajib membayar pinjaman yang diberikan kreditur tepat dengan waktu yang disepakati (Kasmir, 2003:72). Langkah untuk menghindar dari persebaran data yang abnormal maka dilakukan perubahan dengan bentuk logaritma (Ln) pada sampel dikarenakan terdapat selisih jumlah kredit yang cukup besar pada setiap bank. Maka, tingkat perkembangan dan penyaluran kredit bisa diketahui pada persamaan (1).

PenyaluranKredit $=$ Ln $($ PenyaluranKredit $)$

\section{Dana Pihak Ketiga}

Menurut Kasmir (2008), bank memiliki kegiatan yang salah satunya yaitu kegiatan menghimpun dana yang berasal dari masyarakat serta dilakukan penyaluran dana yang dihimpun untuk masyarakat yang memerlukan dana dengan bentuk kredit. Dana Pihak Ketiga (DPK) ialah dana simpanan meliputi tabungan, giro, dan deposito (Ismail, 2010). Untuk menghindari sebaran data yang abnormal maka dilakukan perubahan ke wujud logaritma natural (Ln) pada sampel DPK dikarenakan terdapat selisih jumlah DPK yang cukup besar pada setiap perbankan. Maka, variabel DPK dihitung menggunakan persamaan (2).

$$
\text { DPK }=\text { Ln(Tabungan }+ \text { Deposito }+ \text { Giro }) \text {. }
$$

\section{Capital Adequacy Ratio}

CAR ialah rasio permodalan yang bertujuan memperlihatkan keterampilan perbankan saat mempersiapkan dana yang berguna ketika bank melakukan peningkatan usaha dan juga digunakan untuk menanggung terjadinya kerugian yang berdasar dari aktivitas operasional yang dilaksanakan oleh perbankan. Variabel CAR dirumuskan menggunakan persamaan (3) (Sari, 2013).

$$
C A R=\frac{M O D A L}{A T M R} \times 100 \%
$$


Rurun Ayu Anggraini. Analisis Faktor-faktor yang Memengaruhi Penyaluran Kredit pada Bank Konvensional Periode 2015-2019

\section{Return on Assets}

ROA ialah rasio yang dipakai guna menghitung tingkat optimal pada aktiva yang terdapat pada bank untuk memperoleh keuntungan (laba). Bank Indonesia menetapkan nilai minimum ROA yakni sebesar 2\%. Variabel ROA dihitung menggunakan persamaan (4) (Febrianto, 2013).

$$
R O A=\frac{\text { Laba sebelum pajak }}{\text { rata }- \text { rata totalaset }} \times 100 \%
$$

\section{Non Performing Loan}

Menurut Darmawan (2018), NPL atau yang biasa disebut kredit bermasalah ialah rasio yang digunakan perbankan dalam memperkirakan kemampuan untuk menutupi risiko gagal bayar kredit yang dilakukan debitur. Peraturan Otoritas Jasa Keuangan Nomor 4 /POJK.03/2016 menyatakan Non Performing Loan (NPL) diatur tidak dapat melampaui 5\%. Variabel NPL dihitung menggunakan persamaan (5).

$$
N P L=\frac{\text { Jumlah Kredit Bermasalah }}{\text { Total Kredit }} \times 100 \%
$$

\section{Loan to Deposit Ratio}

LDR ialah rasio untuk mengetahui kemampuan bank dalam membayar kewajiban jangka pendeknya melalui perbandingan himpunan dana dari masyarakat dengan kredit yang diberikan oleh bank (Febrianto, 2013). Variabel LDR dihitung menggunakan persamaan (6).

$$
L D R=\frac{\text { Kredit }}{D P K} X 100 \%
$$

\section{Hubungan antar Variabel}

DPK ialah sumber keuangan yang penting guna aktivitas operasional bank, di mana DPK ada pada masyarakat baik personal atau badan usaha. DPK berwujud tabungan, giro, dan deposito. Bank mengumpulkan dananya dari masyarakat, maka bank berkewajiban mengalokasikan kembali dana tersebut ke masyarakat berupa kredit, bank akan lebih banyak melakukan penyaluran dana dalam wujud kredit apabila bank makin banyak menghimpun dana yang berasal dari masyarakat (Murdiyanto, 2012). Menurut Ayu \& Purnawati (2017), DPK berpengaruh positif terhadap penyaluran kredit. Menurut Wulandari (2013), DPK tidak berpengaruh terhadap penyaluran kredit. Peningkatan DPK akan dapat memengaruhi kecukupan bank dalam menyalurkan dananya. Peningkatan DPK menandakan dana yang diolah bank semakin banyak yang akan mengakibatkan bank akan mendapatkan keuntungan yang meningkat juga (Pratiwi \& Hindasah, 2014).

H1: Dana pihak ketiga berpengaruh positif terhadap penyaluran kredit.

CAR adalah rasio kecukupan modal yang bertujuan guna memperlihatkan kesanggupan perbankan untuk mempersiapkan dana yang berguna dalam peningkatan usaha dan juga digunakan untuk menanggung terjadinya kerugian yang bersumber dari kegiatan operasi yang dilaksanakan oleh perbankan (Sari, 2013). Tingginya CAR dapat menjelaskan bahwa bank mempunyai permodalan yang tinggi, maka dari itu hal tersebut menunjukkan pengaruh terhadap kegiatan operasi bank yaitu penyaluran kredit serta tingginya kecukupan modal menandakan meningkatnya volume kredit bank (Ayu \& Purnawati, 2017). Tingginya CAR dapat berguna untuk peningkatan usaha serta dapat digunakan untuk mengcover adanya kerugian yang akan terjadi akibat kegiatan bank yang menyalurkan kredit pada masyarakat. CAR memiliki pengaruh signifikan positif terhadap penyaluran kredit Amelia \& Murtiasih (2017). Menurut Panuntun \& Sutrisno (2018), CAR memiliki pengaruh signifikan negatif terhadap penyaluran kredit. Hal ini berbeda dengan Ayu \& Purnawati (2017) yang menyatakan CAR tidak memiliki pengaruh terhadap penyaluran kredit.

H2: Capital Adequacy Ratio berpengaruh positif terhadap penyaluran kredit. 
ROA ialah rasio perhitungan tingkat optimal pada aktiva bank untuk memperoleh keuntungan (Febrianto, 2013). Return on Assets (ROA) adalah kemampuan suatu perbankan guna mendapatkan laba berdasarkan aktivitas yang telah dilakukan, maka ROA akan berpengaruh positif. Bank memiliki Return on Assets (ROA) yang besar maka akan membuat bank mendapatkan keuntungan yang meningkat juga sehingga bank dapat melakukan penyaluran kredit lebih tinggi. Putri \& Akmalia (2016) berpendapat bahwa Return on Assets (ROA) berpengaruh positif signifikan terhadap penyaluran kredit. ROA berpengaruh signifikan negatif terhadap penyaluran kredit (Syukriyah et al., 2018). Sedangkan, Febrianto (2013) menyatakan ROA tidak memiliki pengaruh terhadap penyaluran kredit.

H3: Return on Assets berpengaruh positif terhadap penyaluran kredit.

NPL ialah rasio yang digunakan dalam memperkirakan kemampuan perbankan untuk menutupi risiko gagal bayar kredit yang dilakukan debitur (Darmawan, 2018). Bank dalam menyalurkan kredit apabila tidak menerapkan prinsip kehati-hatian memungkinan akan terjadinya potensi NPL atau kredit bermasalah. Apabila bank mengalami kredit bermasalah maka akan memperburuk kondisi kesehatan bank yang akan mengakibatkan ketidakcukupan bank dalam melakukan penyaluran kredit terhadap masyarakat yang membutuhkan dana. Menurut Yasnur \& Kurniasih (2017), NPL berpengaruh positif signifikan terhadap penyaluran kredit, berbeda dengan Syukriyah et al. (2018) menyatakan bahwa NPL berpengaruh negatif signifikan terhadap penyaluran kredit, sedangkan menurut Panuntun \& Sutrisno (2018), NPL tidak berpengaruh terhadap penyaluran kredit.

H4: Non Performing Loan berpengaruh negatif terhadap penyaluran kredit.

LDR ialah rasio yang membadingkan besarnya kredit yang dialokasikan perbankan dengan dana yang dikumpulkan perbankan (Dendawijaya, 2003). LDR berguna untuk memperkirakan kemampuan perbankan. Perbankan mengutamakan kredit untuk menyelesaikan kewajibanya. Jika LDR tinggi maka kemampuan likuiditas suatu bank menjadi rendah sebab total dana yang berguna dalam menyalurkan kredit akan menjadi besar. Sebaliknya jika LDR rendah akan membuat kemampuan likuiditas suatu bank akan tinggi (Febrianto, 2013). Menurut Amelia \& Murtiasih (2017), LDR berpengaruh positif signifikan terhadap penyaluran kredit. Ini berbeda dengan Panuntun \& Sutrisno (2018) yang menyatakan LDR berpengaruh negatif signifikan terhadap penyaluran kredit, tetapi menurut Putri \& Akmalia (2016), LDR tidak berpengaruh terhadap penyaluran kredit.

H5: Loan to Deposit Ratio berpengaruh positif terhadap penyaluran kredit.

\section{METODE PENELITIAN}

Jenis penelitian tergolong dalam penelitian asosiatif. Penelitian ini memakai jenis data sekunder. Data sampel riset didapatkan dari laporan keuangan tahunan bank konvensional yang tercantum pada Bursa Efek Indonesia (BEI) www.idx.co.id periode 2015-2019. Sampel riset memanfaatkan metode purposive sampling, di mana sampel yang digunakan harus masuk kriteria tertentu sehingga sampel diperoleh sebanyak 24 bank konvensional. Sampel yang digunakan memiliki kriteria: (1) bank konvensional yang telah go public dan sudah tercatat pada Bursa Efek Indonesia (BEI); (2) tersedianya laporan keuangan tahunan bank konvensional serta sudah dipublikasikan saat tempo penelitian periode 2015-2019; (3) tersedianya rasio-rasio yang akan diteliti dan data keuangan yang diperlukan terdapat pada laporan keuangan tahunan bank konvensional selama 5 tahun berurutan; (4) bank konvensional yang termasuk papan utama pada Bursa Efek Indonesia; (5) nilai rasio ROA postif selama 2015-2019. Analisis data riset memakai teknik analisis regresi linear berganda.

\section{HASIL DAN PEMBAHASAN}

Penelitian ini menggunakan penyaluran kredit sebagai variabel dependen, dana pihak ketiga, Capital Adequacy Ratio, Return on Assets, Non Performing Loan, dan Loan to Deposit Ratio menjadi variabel 
Rurun Ayu Anggraini. Analisis Faktor-faktor yang Memengaruhi Penyaluran Kredit pada Bank Konvensional Periode 2015-2019

independen. Data yang digunakan yaitu 24 Bank Umum Konvensional selama 2015-2019, sehingga memiliki sampel data sebesar 120 (24 bank dalam 5 tahun periode penelitian). Pengolahan data menggunakan SPSS Versi 23 yang menggunakan sampel data sebesar 120. Gejala autokorelasi ditemukan pada data, sehingga data tersebut belum memenuhi ketentuan Best Linier Unbised Estimator (BLUE). Guna mengatasi gejala autokorelasi, data yang memiliki nilai ekstrim tidak disertakan dalam pengolahan data selanjutnya. Jumlah sampel data setelah dikurangi data yang outlier adalah sebesar 78 .

Tabel 2.

HASIL UJI ASUMSI KLASIK

\begin{tabular}{lcclc}
\hline \multicolumn{1}{c}{ Uji Asumsi Klasik } & Indikator & Variabel & \multicolumn{2}{c}{ Hasil Uji } \\
\hline Uji Normalitas & Uji Kolmogorov-Smirnov & & Sig: 0,058 & \\
Uji Multikolinearitas & Nilai Tolerance dan VIF & Var & Tolerance & VIF \\
& & DPK & .599 & 1.669 \\
& & CAR & .773 & 1.293 \\
& & ROA & .846 & 1.181 \\
Uji Heteroskedastisitas & Uji Glejser & NPL & .829 & 1.207 \\
& & LDR & .704 & 1.421 \\
& & Var & Sig & \\
& & DPK & .102 & \\
Uji Autokorelasi & CAR & .278 & \\
\hline
\end{tabular}

Sumber: Output SPSS (2021, data diolah)

\section{Uji Normalitas}

Tabel 2 menunjukkan asymp sig (2-tailed) sejumlah 0,058 yang artinya lebih tinggi dibandingkan 0,05 , maka semua variabel tidak terikat dinyatakan terdistribusi normal.

\section{Uji Multikolinearitas}

Tabel 2 menunjukkan hasil VIF yang lebih kecil dari 10 bagi seluruh variabel independen. Pada nilai tolerance hasil tersebut menyimpulkan bahwa nilai variabel independen lebih besar dari 0,1 . Maka bisa dinyatakan berdasarkan uji multikolinearitas dinyatakan bahwa model regeresi tidak mengalami multikolinearitas.

\section{Uji Heteroskedastisitas}

Tabel 2 menunjukkan nilai sig untuk setiap variabelnya lebih besar dari 5\% $(0,05)$. Variabel-variabel independen dinyatakan bebas dari heteroskedastisitas dikarenakan nilai sig $>0,05$.

\section{Uji Autokorelasi}

Berdasarkan Tabel 2, telah dilakukannya perbaikan untuk masalah autokorelasi dengan memakai cara Lag satu residual. Dengan demikian, nilai Durbin Watson menjadi 1,844. Apabila dimasukkan pada persamaan $\mathrm{dU}<\mathrm{dw}<4$-dU, nilainya menjadi $1,7708<1,844<2,229$. Maka, model regresi tidak mengalami autokorelasi.

\section{Uji F (Simultan)}

Berdasarkan Tabel 3, nilai signifikansi yaitu $0,00<0,05$. Hasil Uji F menunjukkan nilai sig lebih kecil dari 0,05 maka seluruh variabel independen memiliki pengaruh terhadap variabel penyaluran kredit secara bersamaan.

\section{Uji t}

Berdasarkan Tabel 3, persamaan regresi linier berganda dapat dilihat di persamaan (7). 
Tabel 3.

HASIL UJI HIPOTESIS DAN UJI KOEFISIEN DETERMINASI

\begin{tabular}{|c|c|c|c|c|c|}
\hline \multirow{3}{*}{$\overline{\text { Uji t }}$} & Jenis Uji dan Variabel & Adujusted $R^{2}$ & B & $\mathbf{T}$ & Sig. \\
\hline & (Constant) & & $-5.810 \mathrm{E} 7$ & -4.897 & .000 \\
\hline & DPK & & 987 & 45.856 & .000 \\
\hline & CAR & & 536163.824 & 1.875 & .065 \\
\hline & ROA & & -696963.289 & -.494 & .623 \\
\hline & NPL & & 1238707.889 & 1.221 & .226 \\
\hline & LDR & & 493296.872 & 4.568 & .000 \\
\hline Uji F & Uji Koefisien Determinasi & .980 & & & .000 \\
\hline
\end{tabular}

Sumber: Output SPSS (2021, data diolah)

Sesuai dengan persamaan regresi linier berganda tersebut, hasil koefisien regresi dana pihak ketiga sebesar (+) 0,987. Nilai koefisien tersebut mengindikasi adanya pengaruh positif variabel dana pihak ketiga dengan penyaluran kredit. Capital Adequacy Ratio mempunyai hasil koefisien regresi sejumlah (+) 536163,824. Hal tersebut mengindikasi bahwa variabel CAR memiliki korelasi positif terhadap penyaluran kredit. Koefisien regresi Return on Assets sejumlah (-)696963,289. Koefisien regresi tersebut mengindikasikan adanya hubungan negatif antara ROA terhadap penyaluran kredit. Non Performing Loan memiliki nilai koefisien regresi sejumlah (+) 1238707,889. Koefisien tersebut mengindikasi variabel NPL mempunyai korelasi positif bagi penyaluran kredit. Sedangkan, Loan to Deposit Ratio mempunyai hasil koefisien regresi sejumlah $(+) 493296,872$. Koefisien tersebut mengindikasi adanya hubungan positif antara variabel LDR terhadap penyaluran kredit.

\section{Koefisien Determinasi}

Berdasarkan Tabel 3, nilai Adjusted $\mathrm{R}^{2}$ 0,980 atau 98\%. Maka, dengan hasil tersebut diketahui bahwa 98\% penyaluran kredit dipengaruhi oleh variabel independen DPK, CAR, ROA, NPL dan LDR sedangkan sisanya sebesar 0,02 atau $2 \%$ dapat diuraikan variabel lain di luar variabel penelitian.

\section{Pengaruh Dana Pihak Ketiga terhadap Penyaluran Kredit}

Sesuai hasil riset mengindikasikan terjadinya pertumbuhan ataupun penurunan DPK selama waktu penelitian akan memengaruhi secara signifikan penyaluran kredit. Semakin besar bank menghimpun dana maka akan memacu terjadinya pertumbuhan penyaluran kredit yang akan diberikan perbankan bagi masyarakat.

Dana pihak ketiga yang dikumpulkan perbankan menjadi sumber utama bank saat menyalurkan dananya kepada masyarakat (kredit) (Pratiwi \& Hindasah, 2014). Kredit menjadi prioritas bank guna pengalokasian dana, hal tersebut sesuai berdasarkan fungsi bank sebagai financial intermediary (Rivai et al., 2013). Hal ini ditandai dengan meningkatnya Dana Pihak Ketiga (DPK) setiap tahunnya sejak 2015 yaitu sebesar 4.238.349 miliar Rupiah serta tahun 2019 sebesar 5.709.670 miliar Rupiah. Dengan meningkatnya DPK, kredit yang disalurkan perbankan konvensional juga akan meningkat. Semula penyaluran kredit tahun 2015 sebesar 4.057.904 miliar Rupiah serta tahun 2019 sebesar 5.391.846 miliar Rupiah (www.ojk.co.id, 2020). Dengan adanya pengaruh positif DPK terhadap penyaluran kredit, hal tersebut menandakan bahwa bank konvensional telah menjalankan peranya dengan baik sebagai lembaga keuangan (Pratiwi \& Hindasah, 2014).

Hasil ini mendukung penelitian Panuntun \& Sutrisno (2018) yaitu terjadi pengaruh secara signifikan positif antara DPK dan penyaluran kredit yang berarti meningkatnya DPK akan menaikkan kredit yang disalurkan sehingga bank akan menyalurkan dananya ke masyarakat berupa kredit. Hasil dana pihak ketiga yang memiliki dampak terhadap penyaluran kredit, maka perbankan harus secara maksimal mengelola dana yang dihimpun menjadi kredit. Jika Dana Pihak Ketiga (DPK) meningkat, masyarakat percaya bahwa bank akan bisa mengatur dana tersebut dengan baik. Hal itu 
Rurun Ayu Anggraini. Analisis Faktor-faktor yang Memengaruhi Penyaluran Kredit pada Bank Konvensional Periode 2015-2019

mengakibatkan permintaan kredit karena kinerja bank yang baik. Hasil penelitian ini mendukung hasil penelitian Dharma (2015).

\section{Pengaruh Capital Adequacy Ratio terhadap Penyaluran Kredit}

Capital Adequacy Ratio terbukti tidak memiliki pengaruh terhadap penyaluran kredit. CAR yang besar akan membuat kemampuan modal suatu bank menjadi tinggi untuk melindungi kemungkinan terjadinya kerugian yang dialami oleh bank. Capital Adequacy Ratio yang tinggi akan menyebabkan semakin kecilnya penyaluran kredit bank karena tingginya Capital Adequacy Ratio (CAR) memungkinan terjadi pengelolaan dana (kredit) yang tidak efisien. CAR minimum ditetapkan oleh bank yakni $8 \%$ kenyataan yang terjadi CAR rata-rata bank umum konvensional yang diteliti sebesar 21.82\% untuk periode 2015-2019 yang jauh diatas ketentuan minimal (www.ojk.co.id, 2020). Peningkatan $C A R$ menunjukkan sumber daya keuangan yang memadai guna meminimalisir risiko kredit yang dialami oleh bank. Menurut Pratiwi \& Hindasah (2014), standar minimum yang sudah ditetapkan akan membuat bank berupaya agar Capital Adequacy Ratio (CAR) mempunyai standar sebesar 8\%, tanpa menghiraukan adanya perubahan kredit yang disalurkan. Meski hasil menunjukkan tidak signifikan, bank tidak seharusnya mengabaikan CAR pada penyaluran kredit, sebab bank akan terganggu akibat bank menyalurkan kreditnya secara berlebihan (Pratiwi \& Hindasah, 2014).

Hasil penelitian ini sesuai dengan penelitian Ayu \& Purnawati (2017) yaitu tidak terjadi pengaruh secara signifikan antara CAR dan penyaluran kredit, berarti tingginya suatu CAR bagi suatu bank tidak akan memengaruhi peningkatan pertumbuhan penyaluran kredit. Dengan hasil tersebut, bank harus memperhatikan akan terjadinya risiko kredit yang akan membuat bank tidak meningkatkan penyaluran kredit untuk melindungi nilai CAR untuk meminimalisir terjadinya risiko kredit. Hal serupa ditunjukkan pada penelitian Wulandari (2013) dan Yasnur \& Kurniasih (2017).

\section{Pengaruh Return on Assets terhadap Penyaluran Kredit}

Sesuai hasil riset mengindikasikan jika nilai perolehan laba yang dihasilkan oleh bank tidak menjadikan tolak ukur bank dalam meningkatkan penyaluran dananya. Hal ini disebabkan bank memilih laba yang diperoleh digunakan untuk investasi (Sari \& Abundanti, 2016). Kondisi tersebut dapat terjadi akibat adanya risiko yang ada saat penyaluran kredit hingga bank lebih memilih untuk mementingkan kualitas kredit yang diberikan. Disamping itu, ROA bukan sumber pendanaan utama kredit bank, yang menunjukkan bahwa meningkatnya atau menurunya rasio ROA pada bank tidak memengaruhi jumlah kredit yang akan diberikan oleh perbankan (Pratiwi \& Hindasah, 2014). ROA bank konvensional pada tahun 2015 -2019 ini memiliki rata-rata sebesar 1,92\%. Rata-rata Return on Assets (ROA) tersebut cukup baik tetapi masih kurang dari besarnya minimum ROA yaitu sebesar 2\% (www.ojk.co.id, 2020). Hal tersebut menunjukkan adanya penurunan laba atau asset pada bank konvensional periode 2015-2019.

Return on Assets (ROA) yang meningkat tidak selalu didampingi dengan meningkatnya penyaluran kredit pada bank sebab terjadi fluktuasi pada Return on Assets (ROA) yang membuat ketidakmampuan mengimbangi peningkatan penyaluran kredit. Peningkatan atau penurunan laba suatu perbankan memiliki hubungan dengan modal yang dimiliki oleh perbankan modal tersebut akan berguna bagi bank agar bank mendapatkan keuntungan dengan penyaluran kredit, sedangkan untuk melindungi terjadinya risiko kredit bermasalah, membagikan deviden ke pemegang saham serta menggunkannya untuk investasi dengan meletakkan dananya pada SBI dengan bebas risiko (risk free) maka akan membuat laba yang dimiliki oleh perbankan akan berkurang karena perbankan akan menggunakan pendapatan yang dimilikinya (Sari \& Abundanti, 2016). Maka, peningkatan ataupun penurunan rasio ROA tidak berdampak pada jumlah penyaluran kredit yang akan diberikan bank.

Hasil penelitian ini mendukung riset Pratiwi \& Hindasah (2014) yaitu tidak terjadi pengaruh secara signifikan ROA terhadap penyaluran kredit. Maka, bank harus lebih meningatkan penyaluran kredit tetapi dengan tetap melaksanakan prinsip kehati-hatian dan juga bank diharapkan meningkatkan pengelolaan dananya agar laba yang dihasilkan meningkat sehingga penyaluran kredit yang diberikan bank juga meningkat. Hasil penelitian ini sesuai dengan hasil penelitian Junita Sari \& Abundanti (2016). 


\section{Pengaruh Non Performing Loan terhadap Penyaluran Kredit}

Sesuai hasil riset NPL tidak memiliki dampak terhadap penyaluran kredit. Hal tersebut memperlihatkan NPL yang tinggi membuat dana yang ada berkurang, apabila dana berkurang akan membuat penyaluran dana kepada masyarakat semakin kecil. Hal tersebut membuat perputaran kas terhambat yang akan menyebabkan bank kurang mampu menyalurkan kreditnya dalam jumlah yang besar (Ayu \& Purnawati, 2017).

Non Performing Loan (NPL) menjadi alat ukur kesehatan suatu bank. Rata-rata Non Performing Loan (NPL) bank konvensional tahun 2015-2019 sebesar 2,72\% yang masih bernilai kecil dan tergolong sehat juga dari ketentuan maksimum NPL yaitu sebesar 5\% (www.ojk.co.id, 2020).

Karena Non Performing Loan bernilai baik dari ketentuan minimum hasil tersebut dimungkinkan karena manajamen terhadap risiko kredit sudah baik yang dijalankan oleh suatu bank yang terbukti dari nilai average NPL tahun 2015-2019. Karena NPL tidak memiliki pengaruh yang berarti NPL bukan merupakan fokus utama bank dalam hal menyalurkan kreditnya. Karena NPL yang tinggi akan membuat risiko kredit yang dimiliki oleh bank menjadi besar. NPL yang tinggi membuat bank lebih selektif serta hati-hati dalam melakukan penyaluran kredit. Maka, untuk mencegah adanya kredit yang tidak tertagih, bank mengupayakan untuk menghindari adanya NPL. Upaya yang akan dilakukan yaitu seperti adanya kebijakan perkreditan, manajemen risiko kredit yang diperketat, serta dilakukannya pengembangan kompetensi bagi para pengelola kredit (Ayu \& Purnawati, 2017). Maka, Non Performing Loan (NPL) tidak dapat diprediksi atau dihindari bank dikarenakan merupakan risiko bawaan.

Hasil riset ini sesuai dengan hasil penelitian Panuntun \& Sutrisno (2018) yaitu tidak adanya pengaruh secara signifikan antara NPL dan penyaluran kredit. Dengan hal itu maka bank harus mengurangi risiko kredit karena NPL yang tinggi membuat premi risiko meningkat yang akan membuat terjadinya peningkatan suku bunga kredit. Tingginya suku bunga kredit menyebabkan permohonan atas kredit berkurang. Non Performing Loan (NPL) yang meningkat akan berakibat terjadinya penyimpanan yang besar, hal tersebut akan membuat modal bank berkurang. Hal ini serupa dengan hasil penelitian Ayu \& Purnawati (2017) dan Haryanto \& Widyarti (2017).

\section{Pengaruh Loan to Deposit Ratio terhadap Penyaluran Kredit}

Peningkatan LDR memberikan dampak bagi kredit yang diberikan bank karena tingginya LDR menandakan bahwa bank mempunyai kemampuan guna memenuhi kewajiban jangka pendeknya seperti mampu merealisasikan permohonan kredit yang diajukan (Amelia \& Murtiasih, 2017). LDR akan mengindikasi peningkatan penyaluran kredit yang dilakukan bank, karena bank optimis akan meningkatnya keuntungan yang akan didapatkan bank dan menurunnya risiko kredit yang dialami bank.

Hasil riset ini mendukung Amelia \& Murtiasih (2017) yaitu adanya pengaruh signifikan positif antara LDR dan penyaluran kredit. Dengan hal itu maka bank harus tetap menjaga pengelolaan himpunan dana dari masyarakat serta penyaluran kredit bagi masyarakat. Karena LDR ialah rasio likuiditas, hal tersebut dapat menunjukkan adanya peningkatan penyaluran kredit. Hal ini juga sesuai dengan hasil penelitian Wulandari (2013) dan Febrianto (2013).

\section{KESIMPULAN}

DPK dan LDR memiliki dampak terhadap penyaluran kredit bank. CAR, ROA, dan NPL tidak terbukti berpengaruh terhadap penyaluran kredit bank. CAR tidak memiliki pengaruh terhadap penyaluran kredit karena tahun 2015-2019 CAR pada bank konvensional memiliki nilai jauh di atas ketentuan nilai minimum CAR yang sudah ditetapkan. ROA tidak memengaruhi karena bukan merupakan sumber pendanaan utama bank serta nilai rata-rata ROA selama tahun penelitian kurang dari nilai minimum ROA yang sudah ditetapkan. NPL tidak memiliki pengaruh terhadap penyaluran kredit karena nilai rata-rata NPL masih tergolong rendah. 
Rurun Ayu Anggraini. Analisis Faktor-faktor yang Memengaruhi Penyaluran Kredit pada Bank Konvensional Periode 2015-2019

Keterbatasan penelitian ini adalah waktu yang digunakan relatif singkat dan keterbatasan jumlah variabel yang dipergunakan dalam penelitian. Penelitian berikutnya diharapkan meningkatkan jumlah variabel yang akan digunakan misalnya ROE dan BOPO karena variabel ROA tidak terbukti memiliki pengaruh terhadap penyaluran kredit. Menambah waktu amatan penelitian dengan total data yang lebih tinggi juga penting supaya data yang digunakan tepat dan rentang waktu penelitian yang lebih lama.

\section{DAFTAR PUSTAKA}

Amelia, K., \& Murtiasih, S. (2017). Analisisi Pengaruh DPK, LDR, NPL dan CAR Terhadap Jumlah Penyaluran Kredit Pada PT. Bank QNB Indonesia, Tbk Periode 2005 - 2014. Jurnal Ilmiah Ekonomi Bisnis, 22(1), 97059. https://media.neliti.com/media/publications/97059-ID-none.pdf

Ayu, I. R., \& Purnawati, N. K. (2017). Faktor - Faktor yang Memengaruhi Kredit Pada Bank Umum Swasta Nasional (BUSN) Devisa. E-Jurnal Manajamen 6(11), 5941-5969. https://ojs.unud.ac.id/index.php/Manajemen/article/view/33268.

CNN. (2017). OJK 'Penyaluran Kredit Hanya Tumbuh 7,8\% di 2016. https://www.cnnindonesia.com/ekonomi/20170203161947-78-191135/ojk-penyaluran-kredithanya-tumbuh-78-persen-di-2016, diakses pada 14 Desember 2020.

CNN. (2019). Meroket dari 2017, Kredit Bank 2018 Capai 12,88 Persen. https://www.cnnindonesia.com/ekonomi/20190111190953-78-360264/meroket-dari-2017kredit-bank-2018-capai-1288-persen, diakses pada 14 Desember 2020.

CNN. (2020). OJK Catat Kredit Perbankan 2019 Tumbuh Melambat Cuma 6 Persen. https://www.cnnindonesia.com/ekonomi/20200116142310-78-465948/ojk-catat-kreditperbankan-2019-tumbuh-melambat-cuma-6-persen, diakses pada 14 Desember 2020.

Darmawan, A. (2018). Influence of Loan Interest Rate, Non-Performing Loan, Third Party Fund and Inflation Rate towards Micro, Small and Medium Enterprises (MSME) Credit Lending Distribution at Commercial Banks in Indonesia. 231(Amca), 308-311. https://doi.org/10.2991/amca-18.2018.84.

Dendawijaya, \& Lukman. (2005). Manajemen Perbankan. Jakarta: Ghalia Indonesia.

Dharma, R. (2015). Analisis Faktor - Faktor yang Memengaruhi Kebijakan Penyaluran Kredit Perbankan ( Studi Kasus Pada Bank Umum Di Indonesia Periode Tahun 2008-2012). Ekobistek Fakultas Ekonomi Universitas Putra Indonesia "YPTK" Padang, 5(1), 37-54. http://lppm.upiyptk.ac.id/ekobistek/index.php/EKOBISTEK/article/view/86.

Febrianto, D. fajar. (2013). Analisis Pengaruh Dana Pihak Ketiga, LDR, NPL, CAR, ROA, dan BOPO Terhadap Jumlah Penyaluiran Kredit (Studi pada Bank Umum yang Terdaftar di Bursa Efek Indonesia Periode Tahun 2009-2012). Diponegoro Journal of Accounting, 2(4), 259-269. https://ejournal3.undip.ac.id/index.php/accounting/article/view/5921.

Haryanto, S. B., \& Widyarti, E. T. (2017). Analisis Pengaruh NIM, NPL, BOPO, BI Rate dan CAR Terhadap Penyaluran Kredit Bank Umum Go Public Periode 2012-2016. Journal of Management, 6(4), 1-11. https://ejournal3.undip.ac.id/index.php/djom/article/view/18062.

Indomaritim.id. (2020). Globalisasi: Pengertian, Dampak dan Manfaat. https://indomaritim.id/globalisasi-pengertian-dampak-dan-manfaat/. Diakses pada 25 Juni 2021

Ismail. (2010). Manajemen Perbankan: Dari Teori Menuju Aplikasi. Jakarta: Kencana. 
Junita Sari, N. M., \& Abundanti, N. (2016). Pengaruh DPK, ROA, Inflasi dan Suku Bunga SBI Terhadap Penyaluran Kredit Pada Bank Umum. E-Jurnal Manajemen Unud, 5(11), 7156-7184. https://ojs.unud.ac.id/index.php/Manajemen/article/view/24029.

Kasmir. (2003). Manajemen Perbankan. Jakarta : PT. Raja Grafindo Persada.

Kasmir. (2008). Bank \& Lembaga Keuangan lainya. Jakarta: PT. Raja Grafindo.

Latumaerissa, J. . (2013). Bank dan Lembaga Keuangan Lain. Jakarta: Salemba Empat.

Murdiyanto, A. (2012). Faktor-Faktor Yang Berpengaruh Dalam Penentuan Penyaluran Kredit Perbankan Studi Pada Bank Umum Di Indonesia Periode Tahun 2006 - 2011. Conference In Business, Accounting, And Management (CBAM), 1(1), 61-75. http://jurnal.unissula.ac.id/index.php/cbam/article/view/123/99.

Nuswandari, C. (2009). Pengungkapan Pelaporan Keuangan dalam Perspektif Signalling Theory. 1(Kajian Akuntansi), Kajian Akuntansi, Vol. 1, no. 1. 48-57, 1979-4886. https://www.neliti.com/publications/247275/pengungkapan-pelaporan-keuangan-dalamperspektif-signalling-theory.

Panuntun, B., \& Sutrisno, S. (2018). Faktor Penentu Penyaluran Kredit Perbankan Studi Kasus Pada Bank Konvensional Di Indonesia. JAD: Jurnal Riset Akuntansi \& Keuangan Dewantara, 1(2), 57-66. https://doi.org/10.26533/jad.v1i2.235.

Pratama, B. A. (2010). Analisis Faktor - Faktor yang Memengaruhi Kebijakan Penyaluran Kredit Perbankan ( Studi pada Bank Umum di Indonesia Periode Tahun 2005 - 2009 ). Tesis Universitas Diponegoro. https://ejournal.undip.ac.id/index.php/jbs/article/view/14464.

Pratiwi, S., \& Hindasah, L. (2014). Pengaruh Dana Pihak Ketiga, Capital Adequacy Ratio, Return Nn Asset, Net Interest Margin Dan Non Performing Loan Terhadap Penyaluran Kredit Bank Umum Di Indonesia. Jurnal Manajemen Bisnis Universitas Muhammadiyah Yogyakarta, 5(2), 192-208. https://journal.umy.ac.id/index.php/mb/article/view/1100.

Purnamasari, A. E., \& Musdholifah, M. (2018). Analisis Faktor Eksternal dan Internal Bank terhadap Risiko Pembiayaan Bank Umum Syariah di Indonesia Periode 2012-2015. BISMA (Bisnis Dan Manajemen), 9(1), 13. https://doi.org/10.26740/bisma.v9n1.p13-25

Putri, Y. M. W. \&, \& Akmalia, A. (2016). Pengaruh CAR, NPL, ROA dan LDR Terhadap Penyaluran Kredit Pada Perbankan. Journal Balance, XIII(2), 82-93, ISSN Print: 1693-9352, e-ISSN: 2614-820X. http://journal.um-surabaya.ac.id/index.php/balance/article/view/1322.

Rivai, V., Basir, S., Sudarto, S., \& Veithzal, A.P, 2. (2013). Commercial Bank Management: Manajemen Perbankan dari Teori ke Praktik. Jakarta: Raja Grafindo Perkasa Sari.

Sari, G. (2013). Faktor-faktor yang Memengaruhi Penyaluran Kredit Bank Umum di Indonesia (Periode 2008.1 - 2012.2). Jurnal Riset Ekonomi, Manajemen, Bisnis Dan Akuntansi, 1(3), 931-941. https://ejournal.unsrat.ac.id/index.php/emba/article/view/2298.

Syukriyah, Maharani, S. N., \& Putri, D. M. (2018). Analysis of the Capital Adequate Ratio ( CAR ), Non- Performing Loans ( NPL ), and Return on Assets ( ROA ) Effect on Credit Distribution of Commercial Banks Listed on the Indonesia Stock Exchange. Internasional Journal of Accounting \& Finance in Asia Pasific, 91-96. http://ejournal.aibpm.org/index.php/IJAFAP/article/view/838

Wulandari, F. (2013). Faktor-faktor yang Memengaruhi Penyaluran Kredit Pada Bank Umum yang 
Rurun Ayu Anggraini. Analisis Faktor-faktor yang Memengaruhi Penyaluran Kredit pada Bank Konvensional Periode 2015-2019

Telah Go Public Periode Tahun 2011-2013. Jurusan Akuntansi Fakultas Ekonomi Dan Bisnis Universitas Dian Nuswantoro Semarang. https://core.ac.uk/download/pdf/35383049.pdf

www.ojk.co.id. (2020). Otoritas Jasa Keuangan. https://www.ojk.go.id/id/kanal/perbankan/data-danstatistik/laporan-profil-industri-perbankan/default.aspx. Diakses pada 10 Desember 2020.

Yasnur, M., \& Kurniasih, A. (2017). Factors Affecting Bank Lending Growth : Cases In Indonesia. International Journal of Scientific and Research Publications, 7(11), 69-76. http://www.ijsrp.org/research-paper-1117/ijsrp-p7110.pdf. 